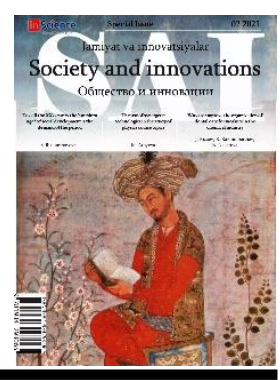

\title{
Conditions for increasing the export of agricultural products in our country in the context of a pandemic
}

\section{Khojiakbar FAYZULLAEV ${ }^{1}$ Umidjon DADABAEV $^{2}$}

Tashkent State University of Economics

\section{ARTICLE INFO}

\section{Article history:}

Received January 2021

Received in revised form

15 January 2021

Accepted 20 February 2021

Available online

7 March 2021

\begin{tabular}{l}
\hline Keywords: \\
Agri-food, food chains \\
Livestock \\
Product net taxes \\
Rural population \\
Pandemic \\
Ranking of EU main agri- \\
food trade
\end{tabular}

Keywords:

Agri-food, food chains

Livestock

Product net taxes

Rural population

Ranking of EU main agri-

Ўзбекистоннинг пандемия шароитида кишлоқ хўжалик махсулотлари экспортини ошириш

\begin{abstract}
This article examines the sectors of the economy of countries during the pandemic, as well as the issues of growing and exporting agricultural products. The article examines the processes of production of vegetables and fruits in the agricultural sector, their processing and high-quality supply of the population and export. In this article, the authors emphasize the importance of reforms and measures taken in our country not only to save the economy in the event of a pandemic, but also to protect our greatest wealth from threats, to ensure their dignified life and long-term development.
\end{abstract}

2181-1415/C) 2021 in Science LLC.

This is an open access article under the Attribution 4.0 International (CC BY 4.0) license (https://creativecommons.org/licenses/by/4.0/deed.ru)

\section{Калит сўзлар: \\ Қишлоқ хўжалиги \\ махсулотлари \\ Озиқ-овқат занжири \\ Озиқ-овқат учун \\ қўлланиладиган соф солиқ \\ Қишлоқ ахолиси \\ Пандемия \\ Европа Иттифоқи билан асосий қишлоқ хўжалиги махсулотлари рейтинги}

\section{АННОТАЦИЯ}

Ушбу мақолада пандемия даврида мамлакатларнинг иқтисодий сохалари, шунингдек қишлоқ хўжалиги махсулотларини етиштириш ва экспорт қилиш масалалари ўрганилди. Мақолада қишлоқ хўжалиги сохасидаги мевасавзовот махсулотлари ишлаб чиқариш, уларни қайта ишлаб ахолига хамда экспортга сифатли етказиб бериш жараёнлари ўрганилди. Ушбу мақолада муаллифлар мамлакатимизда амалга оширилаётган ислохотлар ва кўрилаётган чора-тадбирлар фақатгина пандемия шароитида иқтисодиётни сақлаб қолишга қаратилиб

\footnotetext{
${ }^{1}$ Senior teacher, Tashkent State University of Economics, "Department of World Economy", Tashkent, Uzbekistan

E-mail: barfayz702@gmail.com

${ }^{2}$ Senior teacher, Tashkent State University of Economics, "Department of World Economy", Tashkent, Uzbekistan E-mail: bumid ier@mail.ru
} 
қолмасдан, энг катта бойлигимиз - ахолини хавфхатарлардан химоя қилиш, уларнинг муносиб турмушини таъминлаш ва узоқ истиқболда ривожланишга қаратилгани билан хам ахамияти кўрсатиб ўтилди.

\section{Условия увеличения экспорта сельхоз продукции в нашей стране в условиях пандемии}

\begin{tabular}{l}
\hline Ключевые слова: \\
Агропродовольственные \\
товары \\
Пищевые цепи \\
Чистые налоги на \\
продукты \\
Сельское население \\
Пандемия \\
Рейтинг основной \\
торговли \\
агропродовольственными \\
товарами ЕС
\end{tabular}

АННОТАЦИЯ

Ушбу мақолада пандемия даврида мамлакатларнинг иқтисодий сохалари, шунингдек қишлоқ хўжалиги махсулотларини етиштириш ва экспорт қилиш масалалари ўрганилди. Мақолада қишлоқ хўжалиги сохасидаги мевасавзовот махсулотлари ишлаб чиқариш, уларни қайта ишлаб ахолига хамда экспортга сифатли етказиб бериш жараёнлари ўрганилди. Ушбу мақолада муаллифлар мамлакатимизда амалга оширилаётган ислохотлар ва кўрилаётган чора-тадбирлар фақатгина пандемия шароитида иқтисодиётни сақлаб қолишга қаратилиб қолмасдан, энг катта бойлигимиз - ахолини хавфхатарлардан химоя қилиш, уларнинг муносиб турмушини таъминлаш ва узоқ истиқболда ривожланишга қаратилгани билан хам ахамияти кўрсатиб ўтилди.

\section{INTRODUCTION}

In recent years, serious attention is being paid to increase the national income of the population by the government of Uzbekistan. Especially, many decrees and resolutions of the President and the government orders about preventing pandemic's negative impact on the agricultural sector were adopted in 2020.[1] In fact, Uzbekistan is considered as a double-landlocked country and this is the main issue of selling national products to abroad. As a result, the amount of transportation costs for the delivery of these products to foreign countries increases.

Another main challenge facing agri-food producers today is eliminating the issue of rapid export of our agricultural products to foreign markets, as soon as possible, to solve a number of paperwork and barriers.

It is fact that the pandemic has led to food shortages in many developed countries around the world. The pandemic has led to a significant rise in food prices in local markets. Also, due to the panic among the population, the prices of the most important daily food products have risen sharply. Nowadays, a systematic program has been developed to address a number of this kind of similar problems, in our country. The government has to implement these tasks as a supervisor and a guardian, entrepreneurs as an executor.

\section{MATERIALS AND METHODS}

Due to the sharp increase in demand for agricultural products in the world economy, the world's agricultural developed countries have an opportunity to supply and increase the volume of food and agricultural products on the world market. Many countries around 
the world had already begun to build up their reserves, given the level of preparedness for the second wave of the pandemic, which could lead to shortages of certain types of food.

The main attention of the government in the development of foreign trade in recent years is to further increase the volume of agricultural production and further enhance the image of Uzbekistan in world agriculture. Increasing the number of large refrigerated warehouses needed for storage and logistics of our products, which are grown in the agricultural sector and rapidly lose their quality and deteriorate. So, this is one of the main factors the development of this sector will have a positive impact on the development of our agricultural sector.

According to the data of The State Committee of The Republic of Uzbekistan on statistics, last year only 15\% of Uzbekistan's more than 20 million tons of fruits and vegetables were processed and only $7-8 \%$ were exported. This year, it is planned to increase fruit and vegetable production in the country to at least 30 million tons. As if Uzbekistan exports the surplus agricultural products of its people at the level of international demand, it can earn billions of dollars a year [5].

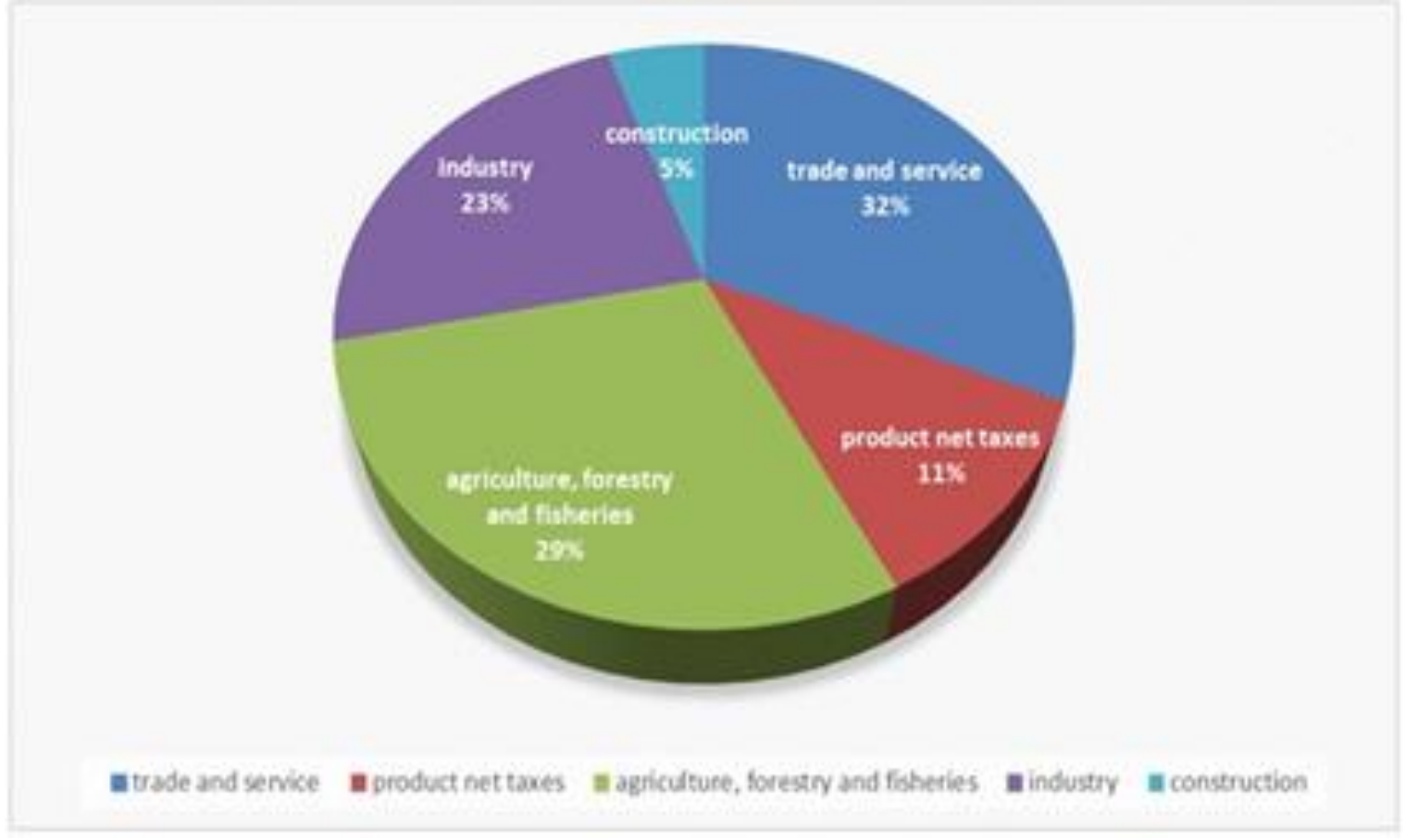

Fig 1: Uzbekistan GDP by sectors in 2018 Source: www.kun.uz

Due to the growing demand for agricultural products in the world agricultural market, as well as the further development of the agricultural sector, which is one of the main sources of income of our national economy, is one of the main tasks of our government. In exporting our national agricultural products to developed countries such as Western Europe, China, Japan, South Korea and other countries, it is necessary to develop foreign marketing to work with large supermarket chains that pay special attention to product quality and origin. Given the pie-chart above shows Uzbekistan gross. domestic product by sectors in 2018. In the current economic crisis caused by the coronavirus pandemic, it is necessary to take reasonable measures to prevent its negative impact on the agricultural sector. It is necessary to reduce the regulatory role of the state in the agricultural sector of the national economy, including the introduction of market 
mechanisms, its further diversification and modernization, as well as, to continue work on attracting both, local and foreign direct and indirect investments.

In developed countries, the demand for agricultural products has increased by twice or three times. For example, one of the most developed countries in the world, the United Kingdom, has never had such a major demand in food and agricultural products in its economic history. From the first days of the pandemic, the local population was shocked by the shortage of food and agricultural products. The situation reached such a point that the issue of "food" became the first topical issue before the British government, as the shelves of shops in all major British cities were empty. Local people rushed to buy at least a "3-month supply of food" in stores due to "panic". Even during the second World War, there was not so much "crisis" in Britain. Although the United Kingdom has asked for help in importing food from neighbouring European Union countries on the food issue, sufficient food stocks for each of the European Union has been a major issue during this period. Most importantly, each European Union country has tightly controlled the transportation of excess food from its territory. That's why, the British government has formally asked South Africa, Egypt and India to increase the amount of the products consisted of fruit and vegetables consumed by the population and to deliver them faster. Because the most important task was to get the United Kingdom out of the crisis and get rid of the "panic", as soon as possible.[3]

During the COVID-19 pandemic a number of countries around the world have imposed temporary restrictions on the export of some agricultural products. For example, European Union countries have introduced a certain norm of export of some agricultural products and a temporary restriction on the export of some products. The neighbouring country -Republic of Kazakhstan has also introduced export quotas for wheat and flour from the $1^{\text {st }}$ April in 2020. Typically, export quotas lead to a decrease in imports of these products to consumer countries. However, the negative impact of these restrictions will certainly not be as impressive for agriculturally developed countries.[2]

Table 1. Ranking of EU main agri-food trade partners and Uzbekistan

\begin{tabular}{|l|l|l|l|l|l|l|l|}
\hline № & $\begin{array}{l}\text { Top } \\
\text { Destinations: } \\
\mathbf{2 0 1 9}\end{array}$ & $\begin{array}{l}\text { Value } \\
\text { Mio € }\end{array}$ & $\begin{array}{l}\text { \% Share } \\
\text { Extra-EU }\end{array}$ & № & $\begin{array}{l}\text { TopOrigins: } \\
\mathbf{2 0 1 9}\end{array}$ & $\begin{array}{l}\text { Value } \\
\text { Mio € }\end{array}$ & $\begin{array}{l}\text { Share } \\
\text { Extra- } \\
\text { EU }\end{array}$ \\
\hline $\mathbf{1}$ & $\begin{array}{l}\text { United } \\
\text { Kingdom }\end{array}$ & 41215 & 22.7 & $\mathbf{1}$ & $\begin{array}{l}\text { United } \\
\text { Kingdom }\end{array}$ & 16750 & 13.8 \\
\hline $\mathbf{2}$ & USA & 21851 & 12.0 & $\mathbf{2}$ & Brazil & 10760 & 8.8 \\
\hline $\mathbf{3}$ & China & 14491 & 8.0 & $\mathbf{3}$ & USA & 10182 & 8.4 \\
\hline $\mathbf{4}$ & Switzerland & 8376 & 4.6 & $\mathbf{4}$ & Ukraine & 7024 & 5.8 \\
\hline $\mathbf{5}$ & Japan & 7280 & 4.0 & $\mathbf{5}$ & China & 5331 & 4.4 \\
\hline $\mathbf{6}$ & Russia & 7027 & 3.9 & $\mathbf{6}$ & Switzerland & 4598 & 3.8 \\
\hline $\mathbf{7}$ & Norway & 4457 & 2.5 & $\mathbf{7}$ & Argentina & 4365 & 3.6 \\
\hline $\mathbf{8}$ & Saudi Arabia & 3649 & 2.0 & $\mathbf{8}$ & Turkey & 4197 & 3.5 \\
\hline $\mathbf{9}$ & Canada & 3549 & 2.0 & $\mathbf{9}$ & Indonesia & 3882 & 3.2 \\
\hline $\mathbf{1 0}$ & Turkey & 3413 & 1.9 & $\mathbf{1 0}$ & Ivory Coast & 3265 & 2.7 \\
\hline $\mathbf{1 1}$ & Australia & 3000 & 1.6 & $\mathbf{1 1}$ & India & 2609 & 2.1 \\
\hline $\mathbf{1 2}$ & South Korea & 2969 & 1.6 & $\mathbf{1 2}$ & Morocco & 2299 & 1.9 \\
\hline
\end{tabular}




\begin{tabular}{|l|l|l|l|l|l|l|l|}
\hline $\mathbf{1 3}$ & Hong Kong & $2 \mathbf{7 9 7}$ & 1.5 & $\mathbf{1 3}$ & Peru & 2254 & 1.9 \\
\hline $\mathbf{1 4}$ & Algeria & 2493 & 1.4 & $\mathbf{1 4}$ & Vietnam & 2161 & 1.8 \\
\hline $\mathbf{1 5}$ & Ukraine & 2455 & 1.4 & $\mathbf{1 5}$ & Canada & 2044 & 1.7 \\
\hline $\mathbf{1 6}$ & $\begin{array}{l}\text { United Arab } \\
\text { Emirates }\end{array}$ & 2387 & 1.3 & $\mathbf{1 6}$ & South Africa & 2002 & 1.6 \\
\hline $\mathbf{1 7}$ & Israel & 2014 & 1.1 & $\mathbf{1 7}$ & Colombia & 1934 & 1.6 \\
\hline $\mathbf{1 8}$ & Singapore & 1943 & 1.1 & $\mathbf{1 8}$ & Chile & 1928 & 1.6 \\
\hline $\mathbf{1 9}$ & Egypt & 1879 & 1.0 & $\mathbf{1 9}$ & Malaysia & 1766 & 1.5 \\
\hline $\mathbf{2 0}$ & Brazil & 1799 & 1.0 & $\mathbf{2 0}$ & Thailand & 1616 & 1.3 \\
\hline $\mathbf{8 9}$ & Uzbekistan & 163 & 0.1 & $\mathbf{9 5}$ & Uzbekistan & 39 & 0.0 \\
\hline & $\begin{array}{l}\text { Rest of the } \\
\text { World }\end{array}$ & $\mathbf{4 2 7 8 3}$ & $\mathbf{2 2 . 4}$ & $\begin{array}{l}\text { Rest of the } \\
\text { World }\end{array}$ & $\mathbf{3 0 6 7 7}$ & $\mathbf{2 4 . 2}$ \\
\hline
\end{tabular}

Source: AGRI-FOOD TRADE STATISTICAL FACTSHEET European Union - Uzbekistan, 2020.

From the table showed above, Uzbekistan has to improve It's agri-food export value with EU countries. Russia and Kazakhstan have been the main importers of Uzbek agricultural products for many years. Therefore, it is desirable to build new markets, trade and logistics centers in the remote regions and territories of Russia, which has a huge territory and a population of about 150 million people.[4]
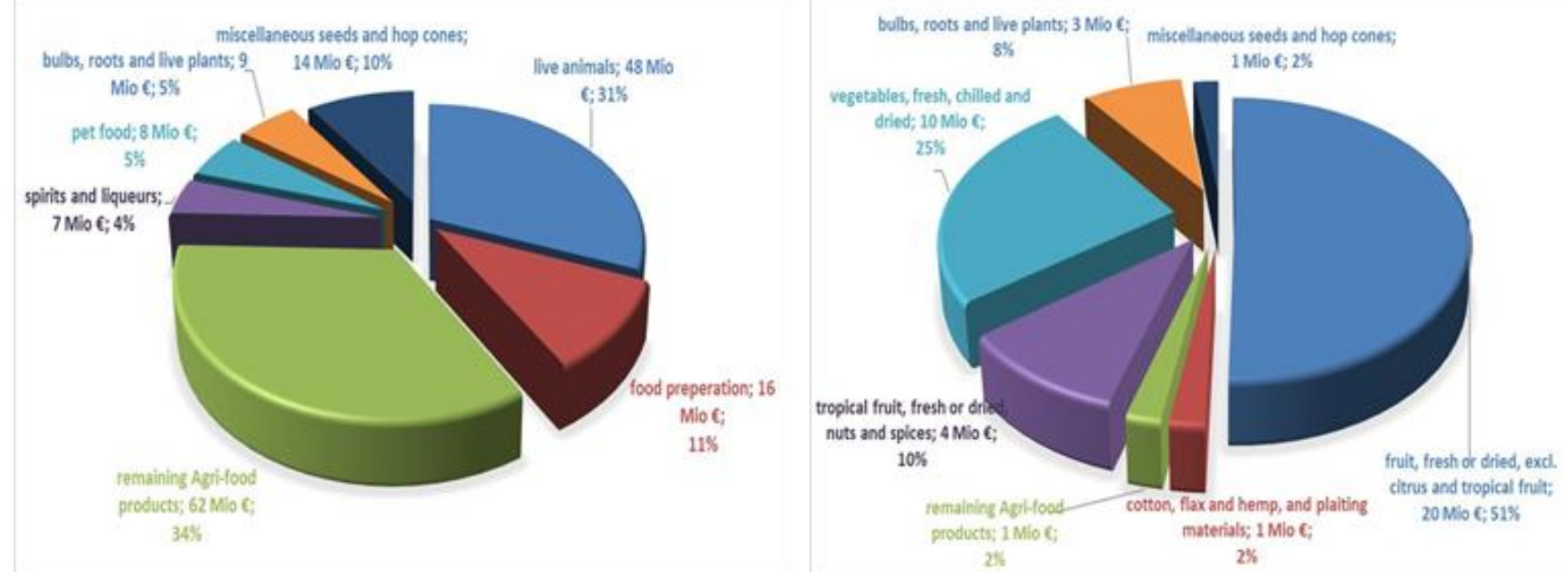

Fig. 2. Top European union Agri-food exports to Uzbekistan in 2019[7] Source: Agri-Food Trade Statistical Factsheet, European Union - Uzbekistan, 2020.

The two pie-charts above describes EU and Uzbekistan export-import structure in 2019. As well as the need to further develop the exchange of agricultural products between European Union and Uzbekistan. Especially, Uzbekistan has to diversify structure of export products and increase the value of turnover.

The World Bank provided Uzbekistan with \$ 500 million for the implementation of a project to modernize agriculture. The project will be financed with funds from the International Bank for Reconstruction and Development and the International Development Association in the amount of \$ 276 million and \$224 million, respectively.[3] 


\section{RESULTS}

In the video conference dedicated to the agricultural sector under the leadership of the President of the Republic of Uzbekistan Sh. Mirziyoyev on September 21, 2020 with the participation of heads of ministries and departments, the head of the government ordered to increase agricultural exports to $\$ 3$ billion cooperation with the Baltic States, Ukraine, Georgia and Eastern Europe. It is mentioned that systematic work will be organized in the delivery of products to new markets.

On October 20, 2018, the Cabinet of Ministers adopted a resolution "On measures to implement national goals and objectives in the field of sustainable development until 2030".

The resolution of the President of the Republic of Uzbekistan "On additional measures to ensure food security, rational use of available resources, state support of agriculture during the coronavirus pandemic":

- introduction of decommissioned lands with available groundwater reserves, introduction of the following procedure for their allocation to the population on preferential terms for the cultivation of agricultural products;

- sell the agricultural lands to the people, first of all who needs to social protection, maximum 1 hectare only for agriculture, as an exception, for 10 years for rent or in prepayment condition to private business entities for 5 hectares for 10 years by e-auction way;

- based on the rent agreement between the initiator and the governors on the allocation of these lands, the decision of the district governor is made, which provides for the use of water-saving technologies and priority planting of vegetables, melons, potatoes, legumes and oilseeds, orchards and vineyards.

\section{DISCUSSION}

Moreover, in the decree of The President of The Republic of Uzbekistan, № PQ-4575 about the strategies of the development of agriculture of The Republic of Uzbekistan for 2020-2030, in 2020 some orders, in food security system, are going to be implemented. Such as, "Development and implementation of state policy on food security" sphere, from October 2020, a system of interventional procurement will be gradually introduced in order to provide the population with uninterrupted supply of grain products and prevent sharp price fluctuations.[6]

The gradual reduction of state order volumes for grain from the 2021 harvest, including the introduction of market mechanisms that ensure free competition in the purchase and sale of grain.

The execution of such measures will lead to a growth in the incomes of local farmers and agri-enterprisers by increasing their production efficiency and expanding their export potential. To achieve these goals, it is important to expand financial and technical assistance as a result of economic cooperation between our country and international financial companies. In particular, the financial support of the World Bank and the Asian Development Bank is very important for the development of our national economy.

\section{CONCLUSION}

In conclusion, the state and international organizations provide a lot of support to entrepreneurs engaged in the export of agricultural products and the population engaged in this field in our country. This can be learned from the ideas discussed above. Entrepreneurs, who produce agricultural products, have been provided with many 
benefits by the resolutions of the President and local authorities, especially in the context of a pandemic. In such a difficult situation, the works being done to ensure food security is much commendable in our country. Only if the planned works were done in a timely manner, the negative impact of the pandemic on the economy would be reduced.

\section{REFERENCES}

1. Abdullaev R.V., Sodokov Z., Abdirashidov A., Arifjanov G'., Botirova N. Jahon moliyaviy iqtisodiy inqirozi sharoitida oziq-ovqat xavfsizligini ta'minlash masalalari. Tashkent, Movarounnahr published. 2011.

2. Koronavirus pandemiyasi davrida oziq-ovqat xavfsizligini ta'minlash, mavjud resurslardan oqilona foydalanish, qishloq xo'jaligini davlat tomonidan qo'llabquvvatlashning qo'shimcha chora-tadbirlari to'g'risidagi O'zbekiston Respublikasi Prezidenti qarori. 2020 y May. PQ-4700-son

3. Максаковский В.П. Глобальная продовольственная проблема и ее географические аспекты. Moscow. 2003

4. State Committee of the Republic of Uzbekistan on Statistics. Available at: https://stat.uz

5. O’zbekiston agrar sektori: asosiy muammolar, xususiyatlar, islohotlar zaruriyati. Available at: https://kun.uz

6. Tojiyeva Z. 2030 yilgacha bo'lgan davrda BMT global kun tartibining Barqaror rivojlanish maqsadlari. Available at: http://www.biznes-daily.uz

7. National Database of Legislation of the Republic of Uzbekistan Available at: https://lex.uz

8. Sputnik Uzbekistan. Available at: https://uz.sputniknews.ru 